\title{
Mothers' View on Late Postoperative Pain Management by the Nursing Team in Children After Cardiac Surgery ${ }^{1}$
}

\author{
Lucila Castanheira Nascimento ${ }^{2}$ \\ Brisa Soldatelli Strabelli ${ }^{3}$ \\ Fernanda Cristina Queiroz Gomes de Almeida ${ }^{4}$ \\ Lisabelle Mariano Rossato ${ }^{5}$ \\ Adriana Moraes Leite 6 \\ Regina Aparecida Garcia de Lima ${ }^{7}$
}

\begin{abstract}
Postoperative pain management in children is a complex, multidimensional and subjective phenomenon. It represents a challenge for children, parents and health professionals. This study aimed to understand how mothers assess their children's pain management by the nursing team in the late postoperative phase of cardiac surgery. Empirical data collection was carried out through semistructured interviews with 17 mothers who accompanied their children. Data were subject to qualitative analysis, revealing that, for the mothers, taking good care results from the confidence they vest in the nursing team and from the observation of the medication interventions this team performs. Not taking good care of their children is a consequence of lack of information or inadequate communication between the team and the mothers. The results of this study permit identifying aspects that strengthen and weaken nursing care for these clients, contributing to the improvement of the delivered care.
\end{abstract}

Descriptors: Child; Pain, Postoperative; Caregivers; Mothers; Nursing, Team; Pediatric, Nursing.

\footnotetext{
${ }^{1}$ Project Research Group Pesquisa em Enfermagem no Cuidado da Criança e do Adolescente (GPECCA), Escola de Enfermagem de Ribeirão Preto, Universidade de São Paulo, WHO Collaborating Centre for Nursing Research Development, SP, Brazil.

${ }^{2}$ RN, Ph.D. in Nursing, Professor, Escola de Enfermagem de Ribeirão Preto, Universidade de São Paulo, SP, Brazil. E-mail: lucila@eerp.usp.br.

${ }^{3}$ RN. E-mail: brisabelli@yahoo.com.br.

${ }^{4}$ RN, M.Sc. in Nursing. E-mail: fcq_enf@yahoo.com.br.

${ }^{5}$ RN, Ph.D. in Nursing, Professor, Escola de Enfermagem, Universidade de São Paulo, SP, Brazil. E-mail: rossato@usp.br.

${ }^{6}$ RN, Ph.D. in Nursing, Professor, Escola de Enfermagem de Ribeirão Preto, Universidade de São Paulo, SP, Brazil. E-mail: drileite@eerp.usp.br.

${ }^{7}$ RN, Ph.D. in Nursing, Full Professor, Escola de Enfermagem de Ribeirão Preto, Universidade de São Paulo, SP, Brazil. E-mail: limare@eerp.usp.br.
}

Corresponding Author:

Lucila Castanheira Nascimento

Universidade de São Paulo. Escola de Enfermagem de Ribeirão Preto

Av. Bandeirantes, 3900

Bairro Monte Alegre

CEP 14040-902 Ribeirão Preto, SP, Brasil

Email: lucila@eerp.usp.br 


\title{
O manejo da dor em crianças, no pós-operatório tardio de cirurgia cardíaca, pelos profissionais de enfermagem, na ótica das mães
}

O manejo da dor pós-operatória na criança é fenômeno complexo, multidimensional e subjetivo. Constitui-se em desafio, para as crianças, pais e profissionais de saúde. O objetivo deste trabalho foi compreender como as mães avaliam o manejo da dor de seus filhos, implementado pela equipe de enfermagem, no pós-operatório tardio de cirurgia cardíaca. A coleta de dados empíricos foi realizada por meio de entrevista semiestruturada com 17 mães que acompanharam seus filhos. Procedeu-se à análise qualitativa dos dados e se apreendeu que, para as mães, cuidar bem é resultante da confiança que elas depositam na equipe de enfermagem e da observação das intervenções medicamentosas que essa equipe realiza. Não cuidar bem de seus filhos é consequência da falta de informação, ou comunicação inadequada entre equipe e mães. Os resultados deste estudo possibilitam identificar aspectos que fortalecem e fragilizam o cuidado de enfermagem a essa clientela, contribuindo para a melhoria do cuidado prestado.

Descritores: Criança; Dor Pós-Operatória; Cuidadores; Mães; Equipe de Enfermagem; Enfermagem Pediátrica.

\section{EI manejo del dolor en niños, en el posoperatorio tardío de cirugía cardíaca, por los profesionales de enfermería, bajo la perspectiva de las madres}

\begin{abstract}
El manejo del dolor posoperatorio en el niño es un fenómeno complejo, multidimensional y subjetivo; siendo que se constituye en un desafío para los niños, padres y profesionales de la salud. El objetivo de este trabajo fue comprender como las madres evalúan el manejo del dolor de sus hijos, realizado por el equipo de enfermería, en el posoperatorio tardío de cirugía cardíaca. La recolección de datos empíricos fue realizada por medio de entrevista semiestructurada con 17 madres que acompañaron a sus hijos. Los datos fueron analizados cualitativamente. Aprendimos que para las madres cuidar bien es resultante de la confianza que ellas depositan en el equipo de enfermería y de la observación de las intervenciones medicamentosas que ese equipo realiza. El no cuidar bien de sus hijos es consecuencia de la falta de información o comunicación inadecuada entre el equipo y las madres. Los resultados de este estudio posibilitaron identificar aspectos que pueden fortalecer o fragilizar el cuidado de enfermería a esa clientela, de esa manera contribuyendo para la mejoría del cuidado prestado.
\end{abstract}

Descriptores: Niño; Dolor Postoperatorio; Cuidadores; Madres; Grupo de Enfermería; Enfermería Pediátrica.

\section{Introduction}

Pain is an unpleasant sensory and emotional experience, characterized by its complex, subjective and multidimensional nature ${ }^{(1)}$. It involves the organism as a whole, covering physiological, psychological and social aspects in individuals' life. Surgical pain in particular is traumatic and stressful for any individual but, in children, its dimensions are even broader, due to the children's lack of verbal and communicative skills to communicate their pain.
Children submitted to surgeries experience pain in the postoperative period, and the first and most important goal of postoperative analgesics is to relieve this pain ${ }^{(2)}$. Until today, a considerable number of children do not receive any pain medication after surgeries and, moreover, when analgesics are prescribed, this happens below the therapeutic dose, so that the child is undermedicated (3). Nurses' attitudes and inadequate knowledge are some factors for undermedication, 
besides the fact that nurses themselves identify multiple barriers for adequate pain control(4-5).

A recent study ${ }^{(4)}$ identified, based on a literature review, that pain management in children is influenced by inadequate communication between nurses and parents. A vicious circle is established, with prevailing loose relations and discontinuous communication, affecting care quality. There is an urgent need to emphasize to all professionals that relatives are our allies and not adversaries in care delivery to children with pain, as they know the child best and can inform about any change in their condition, even the most subtle ones. Thus, it is fundamental to make efforts for the nursing team active in pediatric units to acknowledge the existence of pain in order to assess and intervene based on each child's reaction and according to their development, establishing care that minimizes their suffering and humanize care ${ }^{(1,6)}$ and incorporating fathers and mothers as partners into this child pain management process.

In that sense, knowing that postoperative pain remains one of the main post-surgical complications and a source of discomfort, mainly in children(7), and that fathers and mothers are important allies for health professionals in relieving their children's pain, this research was proposed to understand how mothers assess their children's pain management which nursing professionals put in practice on the occasion of the child's admission at the pediatric ward in the late postoperative phase of heart surgery.

\section{Method}

This exploratory and qualitative research involved human beings and was therefore submitted to ethical review and follow-up by the Research Ethics Committee at the University of São Paulo at Ribeirão Preto Medical School Hospital das Clínicas (HCFMRP-USP), with a favorable opinion (Process HCRP No 7555/2005). When the research data were collected, participants were informed about the study objectives and received the guarantee of information secrecy. They were also requested permission to record the interviews. Besides, as part of the documentation determined by Law, the Free and Informed Consent Term was elaborated in clear and objective language, in which the research subjects were informed about the research objectives, data collection procedures, possible constraints or benefits, and were guaranteed secrecy and respect for the desire to participate in the research or not. This document was passed to and discussed with the participants before the start of the interview and those who agreed to participate were asked to sign the term and keep a copy.

The study was carried out at the pediatric clinic of a teaching hospital, located in the interior of São Paulo State. The children submitted to heart surgery are forwarded from the Pediatric Intensive Care Center (PICC) to spend the late postoperative phase at this clinic, where they are hospitalized at specific nursing wards for child care and are entitled to the company of one parent or another responsible across the hospitalization period. They receive 24-hour nursing care in rotating shift.

Study participants were 17 (seventeen) mothers who accompanied their children on the occasion of their admission to the pediatric clinic in the late postoperative phase of heart surgery, independently of the period they spend at the PICC. Although the participation of fathers or mothers of children submitted to heart surgery was defined as a research inclusion criterion, only mothers were included in the study, as none of the fathers stayed with their children during the hospitalization period at the time of data collection.

The children's age ranged from one month to five years. There were 11 boys and 6 girls. All children were forwarded to the PICC for the immediate postoperative phase and, when their clinical condition had stabilized, they were transfered to the pediatric clinic for the late postoperative phase. In general, the mothers were interviewed between the second and tenth day after the child's surgery. Only one mother was interviewed on the thirtieth day after her son's heart surgery. All mothers participating in this study are identified with the letter $M$, followed by a number representing the order in which they were included in the research. Hence, M1 was the first mother interviewed and M17 the last.

Two of the authors collected the data at the pediatric clinic between March 2007 and May 2008. Semistructured interviews were chosen as the data collection technique to understand how the mothers perceived the child's pain management by nursing professionals. To start the conversation, we asked them to tell us about the moment of the child's hospitalization, the surgery itself and the stay at the PICC until their admission at the pediatric ward, exploring their perceptions of pain management. The goal of this phase was greater approximation between participants and researchers. After discussing the child's trajectory at the hospital, we elaborated two guiding questions to explore the problem: "tell me about your child's (or the child's name) pain in the late postoperative phase of cardiac surgery" and "how do you think nursing professionals 
can act to relieve the child's pain in the postoperative phase of heart surgery?"

During interaction with the mothers, to the extent that the conversation evolved and according to the particularities of each child's experience, other information was sought for the sake of a better understanding about the study object, such as the child's age, duration of the postoperative phase, hospital admission and previous hospitalizations. All interviews were recorded with the participants' permission and then transcribed, so that we would not lose important details for data analysis. Each mother was interviewed only once. The empirical material was analyzed in steps, according to Mayan's orientations ${ }^{(8)}$ for content analysis. Coding was the first step of content analysis. In this process, we identified the words, phrases, themes or concepts present in the empirical material, so that the underlying patterns could be identified and analyzed. Data were subject to exhaustive reading, underlining significant words or phases in the texts and commenting on highlights in the margins. In the next step, called categorization, we started to organize the information. Then, categories resulted from the previously underlined texts. The choice of categories is the essential procedure in content analysis, as they connect the research objectives and results. The last step was integration, where we attempted to integrate the categories into larger themes, so as to represent the understanding of the children's pain management by nursing professionals from the mothers' perspective.

\section{Results}

According to the mothers, child pain management by nursing professionals results from the strategies they use to assess child care, so as to achieve their expectations. According to the mothers, taking good care results from the confidence they invest in the nursing team and from the observation of this team's medication interventions for the child. The mothers' assessment of the nursing team not taking good care of their children derives from a lack of information or inadequate communication between the team and mothers.

\section{Satisfaction with care: trust in the team and pharmacological interventions}

Throughout the data collection process, the interviewees' reflection about pain management made them affirm constantly that the nursing team delivers excellent care and that they have nothing to complain of
(M1). M1 emphasized the importance of this message by repeating this assertion thrice during the interview. Moreover, the mothers frequently expressed their gratitude for the care their children received in hospital. They highlighted the nursing team's patience with the children and constant observation 24 hours per day and repeated that they wanted to congratulate the nursing team for the way they developed their work.

In parallel with these reports, the mothers describe the families' trajectory in search of the surgical treatment their child needs, expressing the difficulties and feelings along this road in detail. Among the difficulties, they highlighted incomplete information during forwarding and lack of place at the health services. The itinerary the mothers reported was that long that having their child take the surgery was a victory in itself, independently of what the child and companion would face during hospitalization.

Confidence in the team was expressed through the actions the nursing team performed, such as constantly asking the mothers about the child's general condition and presence of pain; careful observation of the child, besides a ready reaction to the mothers' calls and response to their doubts:

Now the nurses who stay [on duty] they do come all the time. Look and see how his milk is, saturation, pressure, all that (M11).

They also underlined that the nursing team professionals are always asking the mothers about aspects, such as diet, medication and evacuations, in the attempt to discover the cause of the children's prolonged crying:

They [nurses] ask what medication she [the child] takes, then check the medication they are giving her, ask about the milk, about everything. They asked if you changed [the diaper], then we go ahead until we reach something (M8).

This set of actions seems to help in strengthening the bond between the team and the mothers, transmitting confidence to the latter.

Another sign of nursing professionals' adequate child pain management was the team's readiness in care delivery to children with pain:

When you call, talk, they [professionals] come and see immediately. When medication is necessary they give it. When you ask any question they answer (M7).

The medication intervention, either on the mothers' request or in accordance with the medical prescription, served as an objective indicator to assess their care. According to them, taking good care means giving the medication (M2) and at the right time, everything correct (M1). It means being alert: They [referring to the nursing team] 
keep a close eye 24 hours per day. (...) The whole night they get in there [referring to the nursing ward] to see her [child]. (...) They prescribe dipyrone [referring to the medication administration] (M3).

Despite the emphasis on reporting that the children were receiving medication for pain relief, many mothers informed not knowing what medication was being administered to the child. Some of them even reported on the use of vitamins (M8) and antibiotics (M16) to relieve their children's pain.

\section{Dissatisfaction with care delivery: lack of information and inadequate communication}

This subtheme is directly related with the mothers' dissatisfaction with the information provided about their children's conditions, the care the child demands after the surgery, the nursing team's lack of credibility in response to their suspicions, such as the presence of pain, and the fact that, during the hospitalization, the nursing professionals did not ask some mothers about the child's pain:

They only ask me: And [child's name], is he allright? (...) So, about the pain, they never even mentioned it and I never said anything either (M4).

The pain [pause], at least the day I got here [nursing ward] with him I didn't think it was a lot [a lot of pain], because they didn't explain, I didn't know. I called the nurse to advise me about what to do, if I could take him [the child on the lap], what I couldn't do (M9).

The statement above reveals the mother's attempt to justify why she did not pay attention to whether the child was facing pain episodes on that occasion or not. The lack of information and need for advice about care for the child are evident in her report.

The lack of dialogue or dissatisfaction in the communication process between mothers and nursing team members seems to contribute to inhibit some of them from exposing their feelings and perceptions about the child's pain and the mothers may be afraid to ask help in this identification, culminating in uncertainty about the child's pain:

I think it is important [for the nurse] to ask [the mothers' opinion about the child's condition], because sometimes the mother wants to talk and sometimes she's afraid. I think it's important to ask, right? To see how the child is doing (M12).

I thought it was pain because he cried. I asked the nurse: So, isn't anything wrong with him? (...) She said it was normal, that it was really like that. (...) I asked if, sometimes, he was feeling something and she said no, that it was due to the surgery, that he was going to cry anyway, that it was the postoperative phase. She said: It's normal mom, it's normal. (...) I think the nurses should pay more attention to what the mothers say (M9).

This participant's experience report evidences her doubts about the possibility that her son was feeling pain and this mother's feeling of powerlessness towards the situation. It also appoints the need to value maternal perceptions about children's behavior as, when observing the child's crying, she could perceive that something was not going as usual.

The mothers' statements revealed the need for information about the pain. A large part of participants do not know that postoperative pain related to heart surgery, for example, results from the thoracic wall and rib trauma. In this sense, the mothers reported not knowing that pain could occur in the postoperative phase and showed that they did not have information about possible pain relief methods, except for the pharmacological way.

Although the empirical material evidences knowledge about this last method, the presence of mistaken concepts was verified, related to medication use for the children's postoperative pain relief, including the fear of addiction. One of the participants described the intensity of her child's pain and her nonpharmacological strategies for relief, which did not work, so that she yielded to medication administration. The excerpt below illustrates this mother's concern with her child's pain relief. It reveals, however, that the child still felt pain when there were means to mitigate it:

She feels so much pain that she gnashes her teeth. (...) Her lips get blue. (...) I think the pain is so strong! (...) Yesterday it went on all day, I did everything I could. The girl here [nursing auxiliary], she wanted to give her dipyrone and I said: No, I will arrange things here and she'll calm down. I went on doing that, and on and on and on and she slept and I put her in the cradle. When I saw that she was going to wake up I already went there to talk to her. (...) When she cried I immediately took her on my lap. Then the girl [nursing auxiliary] said: Mom, I think she's feeling pain. I said: No, don't worry, because she's going to get addicted to medication and I don't want her to get addicted. The other drugs she takes are enough, yet another one, you know? (...) But I'm a mother and when I see that my affection doesn't do it, I say: Look, I've done everything I could and I haven't manage to calm her down. Now give her the dipyrone. (...) One night I walked through the corridors with her and the physician saw it. Then she went there, called the girl [nursing auxiliary] and they gave her dipyrone. It didn't help and they gave the other drug. Then she slept. I hope this gets better one day because depending on drugs [interrupted her statement] (M13). 
Data analysis also evidenced the participants' desire to talk to someone from the health team while the child was in surgery, appointing this moment as proper to minimize anxiety, clarify doubts and even give information about postoperative pain issues for the child.

\section{Discussion}

Authors $^{(9)}$ have argued that, besides the objective aspects of pain assessment, understanding is needed about other contextual data involving the children with pain and their caregivers, so as to establish and put in practice efficient therapeutic approaches. In this sense, valuing the partnership between parents and the health team to relieve the child's postoperative pain represents an important effort for the success of this practice. This involvement and interaction are essential, as parents are able to perceive any alteration in their children's behavior(10-11).

In the mothers' assessment of the child's pain management, it was observed that communication between mothers and nursing professionals plays an important role. The quality of communication may entail benefits as well as difficulties for the child's pain management. One of the aspects the participants appointed to facilitate interaction between mother and nursing team was the opportunity for open communication, with room for dialogue and listening. The nursing professionals' reluctance to get closer to the mothers makes their relationship more difficult and also harms the parents' involvement in the child's care. We know that this frailty in the relation between nursing teams and mothers is a factor that impairs care, as the nursing team spends a long time with the children and, hence, is in an advantageous position to advise fathers and mothers about aspects of their children's postoperative pain and include them in care. Some studies(12-13), however, observe that nurses lack knowledge about the theme, distancing them from fathers and mothers because they feel insecure and threatened. Consequently, the latter may take distance from the professionals, fearing that is the attitude they are expected to take.

The deficit in professional nursing education for child pain management is a reality at health services in our context, as this theme was recently incorporated into higher education curricula. Consequently, the nursing team, lead by a nurse, is influenced by this lack of knowledge, as the fact that nurses are not alert to children's pain problems makes them increasingly less sensitive and commitment to adequate pain management. Simple but extremely important information may not be provided, such as advising the parents about the possibility that their children will feel pain, or even demonstrate retracted behavior, such as quietness $^{(10)}$.

Literature demonstrates that the parents value the contents, moment and way they are offered information, acknowledging and criticizing when the language of written and spoken information sometimes diverges among professionals ${ }^{(14)}$. This difficult can be overcome, and the quality of information provided to the parents can be enhanced to the extent that professionals who recently entered the job market, as well as already active professionals needing permanent education to expand knowledge in this area, can share information and existing and available knowledge on this theme. It should be reminded, however, that transferring scientific knowledge into clinical practice is a slow process permeated by great challenges ${ }^{(15)}$.

Research(11) results evidenced some parents' difficulty to address health professionals in their search for information, out of fear of being considered "a bore" when participating actively in the child's care. In a study at the intensive care unit of a university hospital, aimed at understanding the dimensions of health care, it was observed that, in the care process, health professionals could use rushing and distancing attitudes. In this circumstance, relatives and users feel inhibited to request help or manifest concern(16). This can be one of the explanations for some mothers' passiveness in this study when seeking information about their children's pain or even when perceiving this pain and not mentioning it to the health team. Moreover, it can explain these study participants' constant reports to the researchers that they did not have anything to complain about. The mothers' keynote of satisfaction is also understandable from their perspective, considering that the conquest of surgical treatment is the most important, surpassing even the child's pain. Any effort will be worth it, including not showing any dissatisfaction with nursing team care, such as with respect to the child's pain management.

The mothers adopted medication intervention as the main parameter for their children's adequate pain management. This result strengthens the mothers' knowledge about pharmacological methods as the most important strategy for the child's pain relief and indicates the lack of information about other means to relieve this pain. When the nursing team makes the decision to respond to the mother's demand to take care of the 
child's pain through drug administration, indirectly ends up prioritizing this pain relief method. Thus, professionals lose the opportunity to involve the mother in care and even to advise her towards other experiences and other pain relief methods, also at home.

A study ${ }^{(12)}$ that aimed to describe factors promoting and impeding nurses' use of non-pharmacological measures to relieve the pain of children submitted to surgical procedures demonstrated that work overload does not allow these professionals to use nonpharmacological methods to relieve the child's pain. This is one of the difficulties in our reality, as a large part of nursing professionals work double shifts, making them tired and discouraged to put in practice changes in child care. In addition, these professionals tend to postpone the search or even exclude professional recycling opportunities they are offered through courses, congresses and the like to broaden their knowledge and, consequently, contribute to higherquality care, benefitting both children and their families.
Acknowledging the importance of pain assessment, management and relief, the American Pain Society establishes that this symptom should be considered the "fifth vital sign". The Society calls attention to health professionals' responsibility in the assessment and systematic recording of this phenomenon ${ }^{(17)}$.

\section{Conclusion}

Postoperative pain relief in children is a shared goal for professionals, parents and the children themselves. Through this study, we hope to contribute to broaden the nursing team's understanding of maternal perspectives on their children's postoperative pain management and, thus, to facilitate the choice of strategies to minimize aspects that make interaction between mothers and the team more difficult in childcare. Moreover, we hope to highlight the strengths the mothers highlighted in their children's pain management by nursing professionals, so as to encourage their participation in this process.

\section{References}

1. Gaiva MAM, Dias NS. Dor no recém-nascido: percepção de profissionais de saúde de um hospital universitário. Rev Paul Enferm. 2002; 21(3):234-9.

2. Lellan KM. Postoperative pain: strategy for improving patient experiences. J Adv Nurs. 2004; 46(2):179-85.

3. Helgadóttir HL. Pain management practices in children after surgery. J Pediatr Nurs. 2000; 15(5):334-40.

4. Queiroz FC, Nascimento LC, Lima RAG, Leite AM, Scochi CGS. Manejo da dor pós-operatória na enfermagem pediátrica: em busca de subsídios para aprimorar o cuidado. Rev Bras Enferm. 2007; 60(1):87-91.

5. Vincent CVH, Denyes MJ. Relieving children's pain: nurses' abilities and analgesic administration practices. J Pediatr Nurs. 2004; 19(1):40-50.

6. Pölkki T, Pietilä $A C$, Julkunen KV, Laukkala $H$, Ryhänen $P$. Parental views on participation in their child's pain relief measures and recommendations to health care providers. J Pediatr Nurs. 2002; 17(4):270-7.

7. Nascimento P Jr, Módolo NSP, Rodrigues GR Jr. Analgesia pós-operatória para crianças com menos de 1 ano: análise retrospectiva. Rev Bras Anestesiol. 2002; 52(6):739-46.

8. Mayan MJ. Una introducción a los métodos cualitativos: módulo de entrenamiento para estudiantes y profesionales. Alberta: International Institute for Qualitative Methodology; 2001.
9. Menossi MJ, Lima RAG, Correa AK. A dor e o desafio da interdisciplinaridade no cuidado à criança. Rev. Latino-Am. Enfermagem. 2008; 16(3):489-94.

10. Zisk RY, Grey M, Medoof-Copper BM, Kain ZN. Accuracy of parental-global-impression of children's acute pain. Pain Manage Nurs. 2007; 8(2):72-6.

11. Simons J, Franck L, Roberson E. Parent involvement in children's pain care: views of parents and nurses. J Adv Nurs. 2001; 369(4):591-9.

12. Pölkki T, Pietilä AM, Julkunen KV, Laukkala $H$. Factors influencing nurses' use nonpharmacological pain alleviation methods in paediatric patients. Scand J Caring Sci. 2003; 17:373-83.

13. Manworren RCB. Pediatric nurses' knowledge and attitudes survey regarding pain. Pediatr Nurs. 2000; 26(6):610-4.

14. Kankkunen $P$, Vehviläinen-Julkunen KM, Pietilä AM, Halonen P. Is the sufficiency of discharge instructions related to children's postoperative pain at home after day surgery? Scand J Caring Sci. 2003; 17(4):365-72.

15. Graham ID, Logan J, Harrison MB, Straus SE, Tetroe J, Caswell W, et al. Lost in knowledge translation: time for a map? J Contin Educ Health Prof. 2006; 26(1):13-24.

16. Nascimento KC, Erdmann AL. Compreendendo as dimensões dos cuidados intensivos: a teoria do cuidado transpessoal e complexo. Rev. Latino-Am. Enfermagem. 2009; 17(2):215-21. 17. Hortense $P$, Zambrano $E$, Souza FAEF. Validation of the ratio scale of the differents types of pain. Rev. Latino-Am. Enfermagem. 2008; 16(4):720-6. 